XII Международный симпозиум «Русистика в современном мире»

N. Nyagolova (Veliko Tarnovo, Bulgaria)

\title{
XII International Symposium «Russian Studies in the Modern World»
}

С 11 по 14 октября 2018 г. в Великотырновском университете имени Святых Кирилла и Мефодия (Болгария) состоялся XII Международный симпозиум «Русистика в современном мире». Симпозиум проводился при поддержке МАПРЯЛ, Общества русистов Болгарии, Министерства образования и науки (МOH) Республики Болгария, РКИЦ - г. София, Федерации дружбы с народами России и СНГ. Научный форум был посвящен 55-летию кафедры русистики Великотырновского университета (ВТУ). За 48 лет кафедра проводит симпозиум двенадцатый раз. 93 участника из 10 стран мира (Болгария, Россия, Сербия, Украина, Польша, Япония, Румыния, Италия, Тайвань, Казахстан) заявили и приняли участие в работе Симпозиума.

11 октября, накануне открытия научного форума, в Центральной библиотеке университета прочитали публичные лекции двое из участников Симпозиума: до-

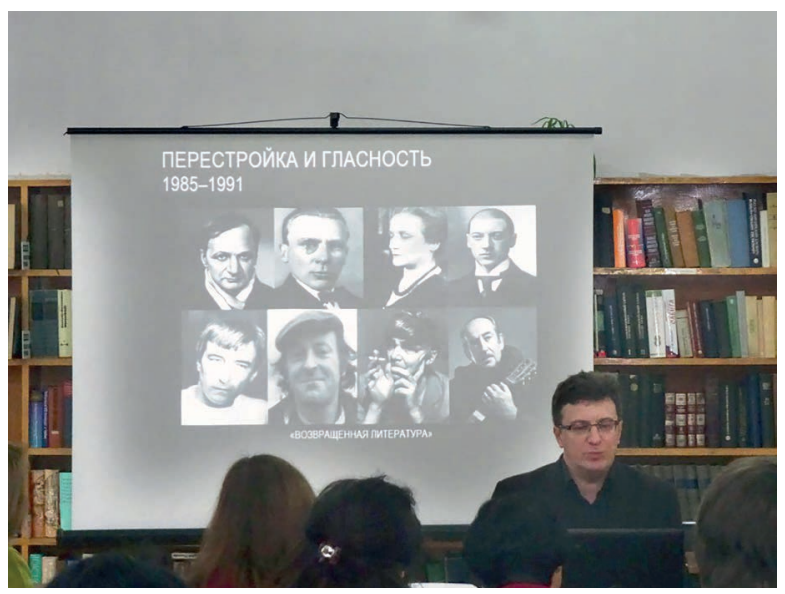

А.Д. Степанов

(профессор Санкт-Петербургского университета) читает лекцию «Современная русская литература» цент, кандидат филологических наук Светлана Юрьевна Артемова (Тверской государственный университет) и профессор, доктор филологических наук Андрей Дмитриевич Степанов (Санкт-Петербургский государственный университет).

Торжественное открытие проводилось в Актовом зале университета. Проректор по международным связям доцент Димитр Димитров открыл Симпозиум. Прозвучали приветственные слова от имени Посольства РФ в Болгарии, Генерального консульства РФ в городе Русе, Российского культурно-информационного центра и Россотрудничества, Министерства образования Болгарии, Общества русистов Болгарии, Федерации дружбы с народами России и СНГ. Декан филологического факультета - профессор, доктор Ценка Иванова и заведующая кафедрой русистики - доцент, доктор Наталия Няголова поприветствовали участников Симпозиума. От имени участников выступила проф. В. Сафонова (МГУ). 


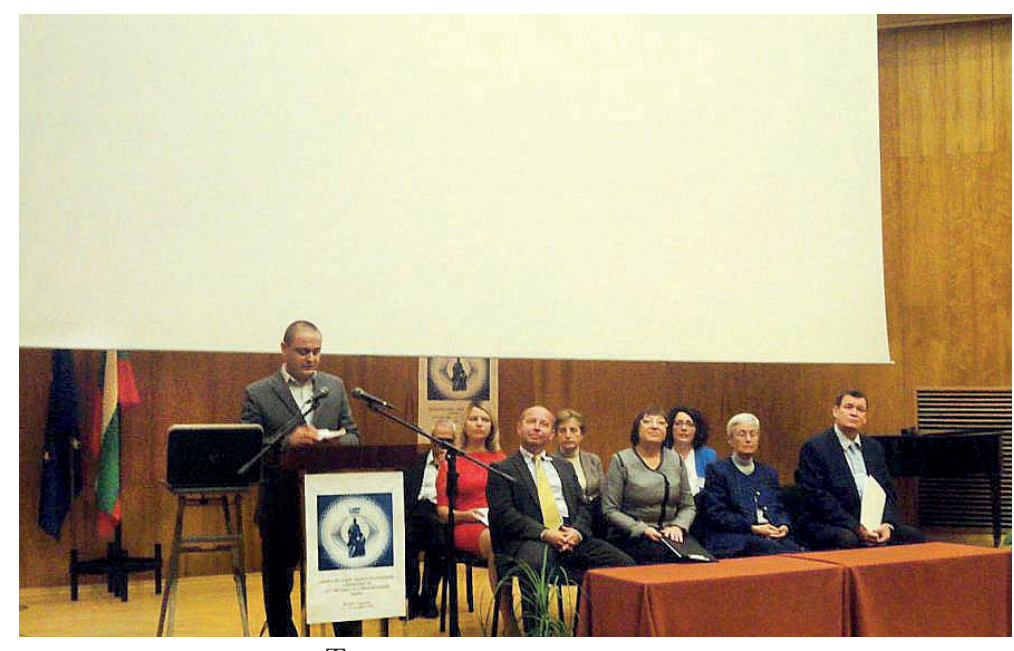

Торжественное открытие

XII Международного симпозиума

«Русистика в современном мире»

Первое пленарное заседание состоялось в Актовом зале. На нем представили свои доклады четверо пленарных докладчиков: профессор, доктор филологических наук Стефана Димитрова (София), профессор, доктор филологических наук Андрей Дмитриевич Степанов (Санкт-Петербург), профессор, доктор Стефка Георгиева (Пловдив), профессор, доктор Лиляна Цонева (Велико-Тырново). Профессор Димитрова говорила о роли экстралингвистического фактора в лингвистических исследованиях. Профессор Степанов представил топику и новаторство современного русского романа. Тема доклада профессора Георгиевой была связана с новой фразеологией новой Европы, а профессор Цонева представила свои наблюдения над современным медиадискурсом.

Работа Симпозиума была организована в семи секциях: «Лексикология. Лексикография. Стилистика», «Словообразование. Морфология. Синтаксис», «Вопросы перевода», «Проблемы методики преподавания РКИ», «Литературоведение», «Прагматика», «Лингвокультурология и история языка».

На втором пленарном заседании выступил с докладом профессор, доктор Гочо Гочев, который познакомил присутствующих с историей Международных симпозиумов в Великотырновском университете. Профессор Л.Г. Бабенко (Екатеринбург) представила новые издания научного коллектива, работющего под ее руководством.

Работа Симпозиума сопровождалась дружеской и продуктивной атмосферой. Участники поделились результатами своих исследований, обсудили актуальные филологические проблемы, установили новые научные контакты. Двенадцатый международный симпозиум «Русистика в современном мире» показал ту роль, которую играет великотырновская русистика в Болгарии, способствуя реализации международной академической программы по изучению русского языка и литературы.

Сведения об авторе:

Наталия Няголова,

канд. филол. наук

доцент

филологический факультет

Великотырновский университет
Natalia Nyagolova,

$\mathrm{PhD}$

Assistant Professor

Faculty of Philology

University of Veliko Turnovo 